\title{
Climatic Trends and Potato Late Blight Risk in the Upper Great Lakes Region
}

\author{
Kathleen M. Baker ${ }^{1}$, \\ William W. Kirk ${ }^{2,4}$, \\ Jeffrey M. Stein ${ }^{2}$, and \\ Jeffrey A. Andresen ${ }^{3}$
}

ADDITIONAL INDEX wORDs. potato late blight, historical trends, disease risk, climate change, Phytophthora infestans

SuMMARY. Concern in the agricultural community over observed and projected climate change has prompted numerous studies on the possible implications for crop yields. However, relatively little work has focused on disease management. In the upper Great Lakes region of the United States, late blight (Phytophthora infestans) of potato (Solanum tuberosum) is a temporally sporadic disease, occurring only when microclimate conditions within the canopy are favorable and inoculum is present. This and other studies indicate that historical climatological trends in the upper Great Lakes region have resulted in warmer and wetter growing season conditions, as well as local increases in precipitation totals and in the frequency of days with precipitation. Consequently, the risk of potato late blight is increasing. Historical trends in hourly weather variables and potato late blight risk as expressed by a modified Wallin disease severity value index were analyzed at seven regional weather stations from 1948-99. All sites showed significant trends in at least one of the risk estimates. While late blight risk was greatest at all locations in August, periods of increasing risk occurred across the region particularly during July. The increases in disease risk appeared to be associated with upward trends in dry bulb and dew point temperature at nearly all

${ }^{1}$ Department of Geography, 3238 Wood Hall, Western Michigan University, Kalamazoo, MI 49008.

${ }^{2}$ Department of Plant Pathology, 35 Plant Biology, Michigan State University, East Lansing, MI 48824.

${ }^{3}$ Department of Geography, 314 Natural Science, Michigan State University, East Lansing, MI 48824.

${ }^{4}$ To whom reprint requests should be addressed. Email: kirkw@msu.edu 
of the stations, especially during July and August. Increased risk of potato late blight has implications for extension agents and commercial horticulturists that include increased emphasis on grower education and application of integrated disease management techniques.

$\mathrm{P}$ otato late blight is a temporally sporadic disease that occurs only when microclimate conditions within the canopy are favorable and inoculum is present (Lacy and Hammerschmidt, 1995). Leaf wetness duration and in-canopy relative humidity are critical variables in determining the relative risk of late blight development. As a result, changes in meteorological variables throughout the growing season that influence the amount of in-canopy moisture and vapor pressure could significantly impact subsequent disease pressure.

This study addresses recent climate trends and their potential impact on potato late blight disease risk in the upper Great Lakes region of the U.S. The influence of climate on disease risk is quantified with a modified Wallin disease severity index (Wallin, 1962). The index is simple and completely dependent on meteorological variables, without considering irrigation, other cultural practices, or pathogen biotype changes that could impact late blight risk. This historical perspective for potato late blight risk characterizes temporal trends in the greater Michigan region from 1948 to 1999.

\section{Materials and methods}

Historical hourly air and dew point temperatures were extracted from the National Climatic Data Center's (NCDC) surface airways data-set (1948-99) for seven first-order National Weather Service (NWS) stations in the greater Michigan region (NCDC, 2004). For each location, shown in Fig. 1, years with missing values for more than $7 \mathrm{~d}$ of the growing season (1 May to 30 Sept.) were not used. Station record lengths ranged from 35 to 49 years for the 52 -year period from 1948 to 1999. Throughout this paper, the station locations are listed in tables and figures in order of latitude, from northernmost to southernmost [i.e., Sault Ste Marie, Mich. (Y62); Alpena, Mich. (APN); Traverse City, Mich. (TVC); Green Bay, Wis.
(GRB), Muskegon, Mich. (MKG); Grand Rapids, Mich. (GRR); Toledo, Ohio (TOL)].

Possible discontinuities in the data series were of concern due to instrument updates, site modifications, and location changes at each of the stations during the period of record. However, Robinson (2000) found that such changes altered temperature measurements less than $1{ }^{\circ} \mathrm{C}\left(1.8^{\circ} \mathrm{F}\right)$. While the overall impact of the gradual shift of the network instrumentation to the current Automated Surface Observing System (ASOS) beginning in the 1990s remains unclear (Robinson, 2000), any impact of series discontinuity relative to the Wallin disease severity index was assumed to be small and the data series were used as recorded.

Potato late blight disease severity values (DSV) were calculated for each day from 1 May through 30 Sept. at each location every year. DSV were based on a modified Wallin method used by Michigan State University
Late Blight Lab (Baker et al., 2000). The five possible disease severity values $(0,1,2,3,4)$ each indicate different types of day relative to disease risk (the greater the number the greater the risk). A relative humidity threshold of $80 \%$ was used to classify hourly values as conducive for late blight if the associated air temperature ranged from 7.2 to $27.0{ }^{\circ} \mathrm{C}$ ( 45.0 to 80.6 $\left.{ }^{\circ} \mathrm{F}\right)$. Hours that were both above the relative humidity threshold and within temperature ranges from 7.2 to 11.7 ${ }^{\circ} \mathrm{C}\left(45.0\right.$ to $\left.53.1^{\circ} \mathrm{F}\right), 11.7$ to 15.0 ${ }^{\circ} \mathrm{C}\left(53.1\right.$ to $\left.59.0^{\circ} \mathrm{F}\right)$, and $15.0-27.0$ ${ }^{\circ} \mathrm{C}\left(59.0\right.$ to $\left.80.6^{\circ} \mathrm{F}\right)$ for a requisite number of hours were assigned the corresponding DSV (Table 1). By convention, daily time periods were initiated at noon local time to include leaf wetness periods associated with the diurnal cycle of dew formation. Due to changes in recording procedure over time in the NWS network, data were available once every $3 \mathrm{~h}$ for a portion of the period of record, in which

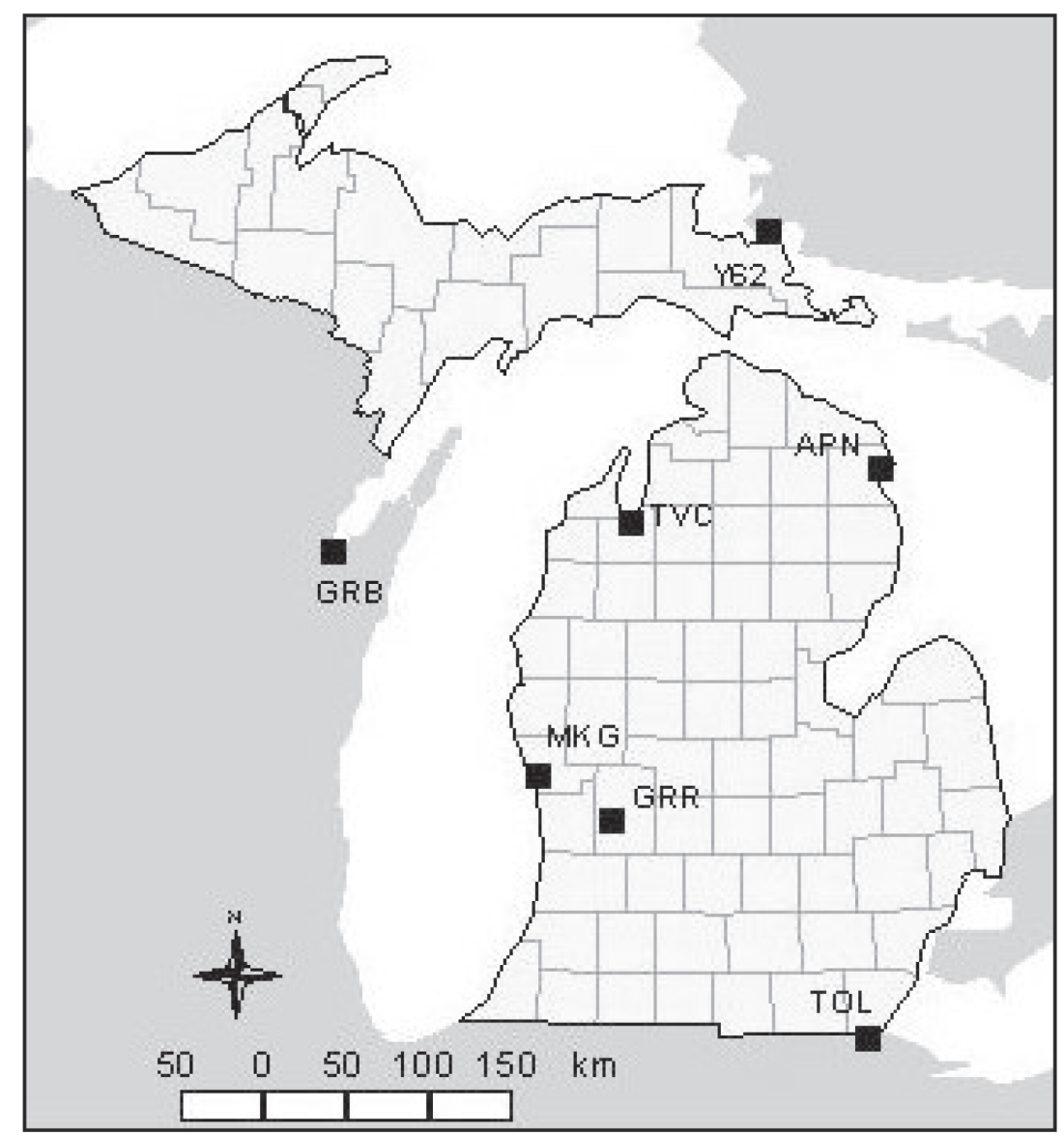

Fig. 1. National Weather Service (NWS) stations used in historical trend analysis: Sault Ste Marie, Mich. (Y62); Alpena, Mich. (APN); Traverse City, Mich. (TVC); Green Bay, Wis. (GRB); Muskegon, Mich. (MKG); Grand Rapids, Mich. (GRR); Toledo, Ohio (TOL). 
case hourly temperature and relative humidity were estimated with linear interpolation.

Trend analysis. Trends in the timing and accumulation of disease severity values were quantified using a non-parametric slope estimator (Sen, 1968). Unlike linear regression, this trend magnitude statistic (B) is not significantly impacted by lack of normality, missing data values and errors that are common in climatological data. This method was used in similar studies of hydrological and climatological time series trend analyses (Andresen et al., 2001 ). When $n$ is the number of observation in a series, $B$ is calculated as:

$$
\mathrm{B}=\operatorname{median}\left\{\mathrm{D}_{\mathrm{ij}}\right\}
$$

where $\mathrm{D}_{\mathrm{ij}}$ is defined as:

$$
\operatorname{Dij}=\frac{\left(x_{j}-x_{i}\right)}{j-i}
$$

for all possible pairs $\left(\mathrm{x}_{\mathrm{i}}, \mathrm{x}_{\mathrm{i}}\right)$ of the data series, $\mathrm{l} \leq \mathrm{i}<\mathrm{j} \leq \mathrm{n}$, and $\mathrm{n}$ is the number of years in the series. Kendall's tau b non-parametric correlation coefficient (SAS; SAS Institute, Cary, N.C.) was used to determine statistical significance of the trends as well as differences between various disease risk indicators, derived as secondary agroclimatic variables from weather data. Trend analysis was performed using time series of the risk indicator variables each growing season from 1948-99 at each location. Kruskall-Wallis one-way analysis of variance on ranks was also used (at the $P=0.05$ level) to test for statistically significant differences between potato late blight risk indicators. Individual risk indicators are described in detail in Table 2.

Types of AsSessed Late blight RisK: SEAsonal DSV accumulation. The seasonal accumulation of DSV, or $\Sigma \mathrm{v}$, is the sum of all individual daily DSV values within a growing season (153 total). Individual daily totals may vary from values of 0 to 4 . Different disease severity values $(0,1,2,3,4)$ indicate different late blight risk related conditions, or a different type of disease risk day. $\Sigma \mathrm{x}_{\mathrm{y}}$ represents $\mathrm{x}$ days in a given growing season with a particular disease severity $y$. The number of days with each specific DSV value, $\Sigma \mathrm{x}_{\mathrm{y}}$ and the number of days with a value greater than zero, $\Sigma \mathrm{x}_{\mathrm{y}>0}$, were compared to determine if trends were related to increasing frequency of a specific type of risk condition. The distribution of $\Sigma \mathrm{x}_{\mathrm{y}>0}$ and the change in $\Sigma \mathrm{x}_{\mathrm{y}}$ distribution

Table 1. Temperature range and duration of relative humidity $(\mathrm{RH})$ used to cal-

\begin{tabular}{|c|c|c|c|c|c|}
\hline \multirow[b]{2}{*}{ Temperature } & \multicolumn{5}{|c|}{$\begin{array}{c}\text { Time at } \geq 90 \% \text { RH required to accumulate } \\
\text { a particular DSV value from } 0-4\end{array}$} \\
\hline & 0 (none) & 1 (minimal) & 2 (slight) & 3 (moderate) & 4 (severe) \\
\hline $\begin{array}{l}7.2 \text { to } 11.7^{\circ} \mathrm{C} \\
\left(45.0 \text { to } 53.1^{\circ} \mathrm{F}\right)\end{array}$ & $<16$ & $16-18$ & $19-21$ & $22-24$ & $\mathrm{n} / \mathrm{a}^{\mathrm{z}}$ \\
\hline $\begin{array}{l}11.7 \text { to } 15.0^{\circ} \mathrm{C} \\
\left(53.1 \text { to } 59.0^{\circ} \mathrm{F}\right)\end{array}$ & $<13$ & $13-15$ & $16-18$ & $19-21$ & $22-24$ \\
\hline $\begin{array}{l}15.0 \text { to } 27.0^{\circ} \mathrm{C} \\
\left(59.0 \text { to } 80.6^{\circ} \mathrm{F}\right)\end{array}$ & $<10$ & $10-12$ & $13-15$ & $16-18$ & $19-24$ \\
\hline
\end{tabular}
culate disease severity values (DSV), adapted from Wallin (1962).

Table 2. Indicators of potato late blight risk estimated for each growing season and location included in the 1948-99 analyses and derived as secondary variables from ambient air temperature, dew point temperature, and time in days during the growing season (1 May through 30 Sept.).

Simplified Description

$\Sigma \mathrm{V}$

$\sum \mathrm{x}_{\mathrm{y}}$

$\mathrm{t}_{\Sigma \mathrm{v}=18}$

$\mathrm{t}_{\Sigma \mathrm{v}=30}$

$\Sigma_{\mathrm{V}>=10}$

$30-\mathrm{d} \Sigma \mathrm{V}$

Number DSV ${ }^{z}$ accumulated per growing season

Total number of days $(\mathrm{x})$ with a particular DSV $(\mathrm{y})$ in a single growing season

Time in days $(\mathrm{t})$ until the growing season accumulation of DSV is equal to 18

Time in days $(t)$ until the growing season accumulation of DSV is equal to 30

Number of 5 -d periods in a single growing season when the accumulated DSV (for those $5 \mathrm{~d}$ ) is equal to at least 10

Number DSV accumulated during a particular period specified by start date and end date during a single growing season

${ }^{2}$ Potato late blight disease severity values (DSV) were calculated using the modified Wallin (1962) method as shown in Table 1.

were also compared at each station location.

TIME TO REACH RISK THRESHOLDS. The time, $t$, in days until the accumulation of DSV, $\Sigma \mathrm{v}$, reached a threshold value, was calculated for fungicide spray triggers at 18 and 30 accumulated DSV. The $18 \mathrm{DSV}\left(\mathrm{t}_{\mathrm{Ev}=18}\right)$ accumulation corresponded to the traditional Wallin model threshold initiation of fungicide sprays (Wallin and Schuster, 1960; Wallin, 1962; MacKenzie, 1981), while $30\left(\mathrm{t}_{\Sigma \mathrm{v}=30}\right)$ was used in the MSU modified system to signal an increase in fungicide application rate from minimum to maximum manufacturer's recommended application rate. In the MSU system, applications of fungicides were recommended to start soon after emergence regardless of conditions, or $\Sigma \mathrm{v}$, in order to prevent initiation of epidemics from late blight contaminated seed.

Consecutive rain days and other relatively short time periods with large DSV accumulations are especially important for management decisions re- lated to late blight control. The number of times during each growing season when the accumulated late blight risk during any 5 - $\mathrm{d}$ time period, $\mathrm{t}_{\mathrm{i} . \mathrm{i}+5}$, was greater than $10(\Sigma \mathrm{v}>10)$ was used to estimate the frequency of canopy conditions that were highly conducive to late blight.

TRENDS IN TIMING OF RISK ACCUMULATION. Trends in 30-d accumulated values were assessed to determine which of those periods within the growing season were most influenced by changing weather patterns. Since no previous research has established an optimal time scale within the growing season for late blight risk, or defined the beginning and end of risk periods seasonally, DSV accumulations were started on the first and 15th of each month May through September. These $30-\mathrm{d}$ periods were then associated with potato canopy leaf area index (LAI) estimates for the growing region (Allen and Scott, 1992). LAI monthly estimates were important to the understanding of how canopy conditions 
relate to those in the ambient air during analyzed time intervals.

Similarly, to determine relationships between trends in late blight risk indicators and the physical environmental variables from which they were derived, monthly dew point temperature $\left(\mathrm{T}_{\mathrm{d}}\right)$ and ambient temperature $\left(\mathrm{T}_{\mathrm{a}}\right)$ were also analyzed for the presence of trends.

\section{Results}

Seasonal DSV accumulation. Time series of annual DSV accumulations, with median value line added and smoothed trend line (9-year moving average) overlaid, are shown in Fig. 2. Across the region, DSV accumulations $(\Sigma \mathrm{V})$ tended to be greater in 1960-62, 1978-79, and 1994-96. From 1948 to 1999 , all $\Sigma_{\mathrm{V}}$ increased with respect to time (Table 3 ). The increases at all sites except Toledo and Traverse City were statistically significant (at the $P$ $=0.05$ level). Increases in $\Sigma \mathrm{v}$ at Sault Ste Marie, Green Bay, Muskegon and Toledo were of similar magnitude, between 0.54 and 0.61 DSV per year from 1948-99. The magnitude of the increases in $\Sigma \mathrm{v}$ at Alpena and Grand Rapids, 1.00 and 1.10 respectively, was nearly double those at the other locations.

Decreases were observed in the number of days with a DSV of $0\left(\Sigma \mathrm{x}_{0}\right)$ at all locations (Table 4 ). The decreases were significant at Sault Ste Marie, Alpena, Green Bay, and Muskegon. Temporal trends for every location and every $\Sigma \mathrm{x}_{\mathrm{y}>0}$ were either positive or near zero. No location exhibited a significant change in $\Sigma \mathrm{x}_{1}$, but at all locations except Traverse City there were significant increases in $\Sigma \mathrm{x}_{2}$. There were significant increases in $\Sigma \mathrm{x}_{3}$ at Green Bay and Alpena, and $\Sigma \mathrm{x}_{4}$ at Grand Rapids and Sault Ste Marie over the 50-year time period.

Threshold anALYsis. The number of days between the start of the growing season and the accumulation points of $18\left(\mathrm{t}_{\Sigma \mathrm{v}=18}\right)$ and $30 \mathrm{DSV}\left(\mathrm{t}_{\Sigma \mathrm{v}=30}\right)$,

Fig. $2(\mathrm{a}-\mathrm{g})$. Disease severity values (DSV) accumulation $(\Sigma \mathrm{v})$ by year for: a) Sault Ste Marie Ste Marie, Mich. (Y62); b) Alpena, Mich. (APN); c)

Traverse City, Mich. (TVC); d) Green Bay, Wis. (GRB); e) Muskegon, Mich. (MKG); f) Grand Rapids, Mich.

(GRR); and g) Toledo, Ohio (TOL).

Values are overlaid with location-specific median value line and smoothed trend line.
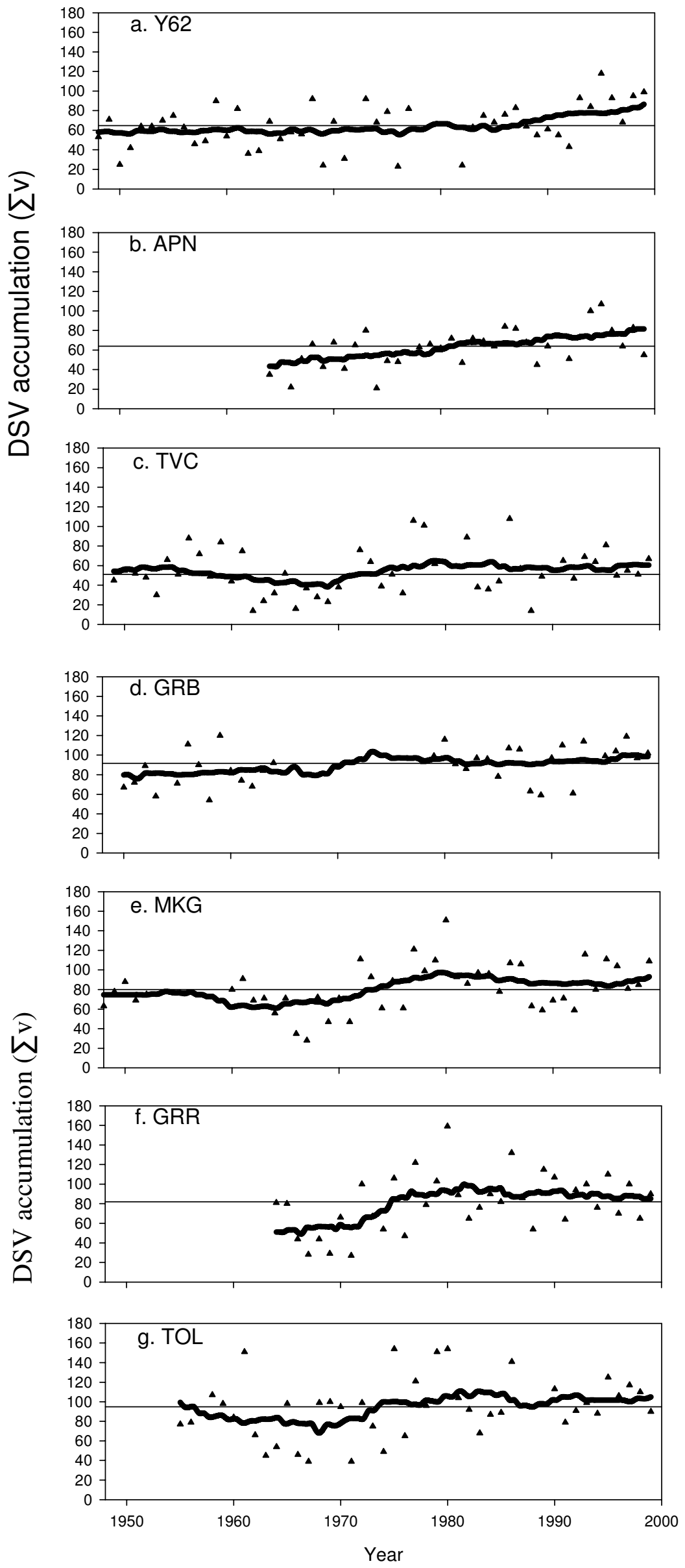
both of which are used as fungicide spray thresholds, exhibited negative slopes with respect to time (Table $5)$. The time in days to reach both thresholds significantly decreased at Grand Rapids and Sault Ste Marie, and $t_{0-30}$ also decreased significantly at Alpena and Toledo from 1948-99 (Table 5).

The rates of change in the numbers of extremely conducive intervals, $\Sigma \mathrm{v}>=10$, for each location from 194899 are shown in Table 5. The increases in the number of these intervals were statistically significant at Grand Rapids, Toledo and Traverse City. The greatest increase in $\Sigma v>=10$ was observed at Traverse City. Increases in $\Sigma \mathrm{v}>=10$ at Green Bay and Muskegon were also positive, but there were no changes in the number of $\Sigma v>=10$ intervals at the two northernmost stations, Sault Ste Marie and Alpena (Table 5).

TIMING OF DISEASE RISK. Results from the analysis of DSV accumulation during $30-\mathrm{d}$ periods throughout the growing season, beginning on the first and 15th of each month at each station, are shown in Table 6. The median 30-d $\Sigma \mathrm{v}$ were consistently lowest at Traverse City, except during the period beginning 15 June, when Alpena was slightly lower. Highest median 30-d $\Sigma v$ generally occurred at Toledo for all periods. The three northernmost locations of Sault Ste Marie, Alpena and Traverse City were not statistically different throughout the season. The median $30-\mathrm{d} \Sigma \mathrm{v}$ of the four southernmost locations of Green Bay, Muskegon, Grand Rapids, and Toledo were significantly different from one another during tow periods (those starting 1 May and 1 July). From 15 June onward, the median $30-\mathrm{d} \Sigma \mathrm{v}$ at Grand Rapids was not significantly different from the medians at the three northernmost stations.

All trends of $30-\mathrm{d} \Sigma \mathrm{v}$ since 1948 were positive with the exception of Muskegon and Grand Rapids during September. Greatest increases occurred during periods beginning 15 June or later. The increase in 30- $\mathrm{d} \Sigma \mathrm{v}$ was statistically significant at Sault Ste Marie, Alpena, Muskegon, and Grand Rapids for periods beginning on both 15 June and 1 July. At Grand Rapids, 30-d $\Sigma$ v increases were statistically significant for periods starting on 15 July and 1 Aug.. The increase in $30-\mathrm{d} \Sigma \mathrm{v}$ at Alpena starting 15 Aug. was also significant. Finally, 30-d $\Sigma \mathrm{v}$ at Toledo increases

Table 3. Analysis of accumulated disease severity values (DSV) per growing season (1 May through 30 Sept.) at seven locations in the greater Michigan region from 1948-99, including a) the median DSV accumulated per growing season and $b$ ) the rate of change in DSV accumulated per growing season.

b) Non-parametric trend $B$

a) Median number DSV accumulated per growing season ${ }^{\mathrm{z}}$

\begin{tabular}{|c|c|c|c|}
\hline & \multirow{2}{*}{$B$} \\
\hline Station ID & $\mathbf{N}^{\mathrm{x}}$ & Median & \\
\hline Y62 & 47 & $64.0 \mathrm{~b}^{\mathrm{w}}$ & $0.55^{* *_{\mathrm{v}}}$ \\
\hline $\mathrm{APN}$ & 35 & $64.0 \mathrm{~b}$ & $1.00^{\star * *}$ \\
\hline TVC & 49 & $51.0 \mathrm{~b}$ & 0.25 \\
\hline GRB & 36 & $92.5 \mathrm{a}$ & $0.56^{\star *}$ \\
\hline MKG & 45 & $80.0 \mathrm{a}$ & $0.54^{*}$ \\
\hline GRR & 36 & $82.0 \mathrm{a}$ & $1.10^{\star}$ \\
\hline TOL & 41 & $95.0 \mathrm{a}$ & 0.61 \\
\hline
\end{tabular}

${ }^{\mathrm{z}}$ Growing season included 1 May through 30 Sept. (153 d)

y National Weather Service (NWS) station locations: Y62 = Sault Ste Marie, Mich.; APN =Alpena, Mich.; TVC= Traverse City, Mich.; GRB=Green Bay, Wis.; MKG=Muskegon, Mich.; GRR=Grand Rapids, Mich.; TOL= Toledo, Ohio.

xThe number of years from 1948-99 with complete data records used for analyses.

"Within a single column, values followed by the same letter are not significantly different at $P=0.05$ (KruskalWallis one-way analysis of variance on ranks).

"Rate of change is significantly greater than zero at $P=0.05\left(^{*}\right), P=0.01\left(^{* *}\right)$, or $P=0.001\left(^{* * *}\right)$ (Kendall Tau b).

Table 4. Analysis of rate of change in number of days of each disease severity value (DSV) per growing season (1 May through 30 Sept.) at seven locations in the greater Michigan region from 1948-99.

\begin{tabular}{|c|c|c|c|c|c|}
\hline \multirow[b]{2}{*}{ NWS station $^{z}$} & \multicolumn{5}{|c|}{$\begin{array}{l}\text { Non-parametric trend (rate of change in } \mathrm{x} \text { per year) } \\
\text { in number of days per growing season } \\
\text { with specific DSV value (y) from } 0 \text { through } 4\end{array}$} \\
\hline & $\sum \mathbf{x}_{0}$ & $\sum \mathbf{x}_{1}$ & $\sum \mathbf{x}_{2}$ & $\sum \mathbf{x}_{3}$ & $\sum \mathbf{x}_{4}$ \\
\hline Y62 & $-0.22^{* \mathrm{y}}$ & 0.03 & $0.08^{*}$ & 0.02 & $0.04^{*}$ \\
\hline $\mathrm{APN}$ & $-0.44^{* *}$ & 0.14 & $0.16^{* *}$ & $0.11^{* *}$ & 0.07 \\
\hline TVC & -0.10 & 0.00 & 0.00 & 0.30 & 0.00 \\
\hline GRB & $-0.19^{*}$ & 0.00 & $0.09^{*}$ & $0.06^{* *}$ & 0.03 \\
\hline MKG & $-0.30^{* *}$ & 0.09 & $0.09^{*}$ & 0.04 & 0.04 \\
\hline GRR & -0.48 & 0.15 & $0.22^{* *}$ & 0.00 & $0.13^{*}$ \\
\hline TOL & -0.25 & 0.06 & $0.13^{*}$ & 0.00 & 0.08 \\
\hline
\end{tabular}

${ }^{2}$ National Weather Service (NWS) station locations: Y62 = Sault Ste Marie, Mich.;APN = Alpena, Mich.; TVC = Traverse City, Mich.; GRB = Green Bay, Wis.; MKG=Muskegon, Mich.; GRR=Grand Rapids, Mich.; TOL= Toledo, Ohio. y Rate of change is significantly greater than zero at $P=0.05\left({ }^{*}\right)$ or $P=0.01\left(^{* *}\right)$ (Kendall Tau b).

Table 5. Analysis of the rate of change in the number of days to disease severity value (DSV) accumulation thresholds of 18 and 30 per growing season and the number of 5-d periods with an accumulation of 10 or more DSV per growing season (1 May through 30 Sept.) at seven locations in the greater Michigan region from $1948-99$.

\begin{tabular}{|c|c|c|c|}
\hline \multirow{2}{*}{$\begin{array}{l}\text { NWS } \\
\text { station }^{z}\end{array}$} & \multicolumn{2}{|c|}{$\begin{array}{l}\text { Non-parametric trend in number } \\
\text { of days ( } t \text { ) (rate of change in } \\
t \text { per year) to DSV accumulation } \\
\text { thresholds per growing season }\end{array}$} & \multirow{2}{*}{$\begin{array}{l}\text { Rate of change in the number } \\
\text { of } 5 \text {-d periods per year } \\
\text { with an accumulation } \\
\text { of } 10 \text { or more DSV } \\
\text { per growing season }\end{array}$} \\
\hline & $\mathbf{t}_{\left(\sum_{v=18)}\right.}$ & $\mathbf{t}_{\left(\sum_{\mathrm{v}=30)}\right.}$ & \\
\hline Y62 & $-0.48^{*_{x}}$ & $-0.45^{*}$ & 0.00 \\
\hline $\mathrm{APN}$ & -0.83 & $-1.08^{\star *}$ & 0.00 \\
\hline TVC & -0.08 & -0.18 & $0.25^{*}$ \\
\hline GRB & -0.14 & -0.21 & 0.05 \\
\hline MKG & -0.32 & -0.33 & 0.07 \\
\hline GRR & $-0.64^{*}$ & $-1.09^{* \star *}$ & $0.14^{*}$ \\
\hline TOL & -0.39 & $-0.47^{\star}$ & $0.13^{* *}$ \\
\hline
\end{tabular}

${ }^{2}$ NationalWeather Service (NWS) station locations: Y62 = Sault Ste Marie, Mich.;APN = Alpena, Mich.; TVC = Traverse City, Mich.; GRB = Green Bay, Wis.; MKG=Muskegon, Mich.; GRR=Grand Rapids, Mich.; TOL= Toledo, Ohio. 'Non-parametric trend in the number of 5 -d periods $\left(t_{i}\right.$ to $\left.t_{i+5}\right)$ with an accumulation of 10 DSV or greater per growing season. 
Table 6. Analysis of disease severity value (DSV) accumulation during 30 -d periods per growing season (1 May through 30 Sept.) at seven locations in the greater Michigan region from 1948-99 including the median DSV accumulation ( $\Sigma v)$ during 30-d periods per growing season and rate of change in DSV accumulation during 30-d periods per growing season (by starting date).

\begin{tabular}{|c|c|c|c|c|c|c|c|c|c|}
\hline \multirow{2}{*}{$\begin{array}{l}\text { NWS } \\
\text { station }^{z}\end{array}$} & \multicolumn{9}{|c|}{ Median DSV accumulation $(\Sigma v)$ during 30 -d periods per growing season ${ }^{y}$} \\
\hline & 1 May & 15 May & 1 June & 15 June & I July & 15 July & 1 Aug. & 15 Aug. & 1 Sept. \\
\hline Y62 & $2.0 \mathrm{C}^{\mathrm{x}}$ & $4.0 \mathrm{c}$ & $7.0 \mathrm{bc}$ & $11.0 \mathrm{ab}$ & $16.0 \mathrm{bc}$ & $20.0 \mathrm{abc}$ & $20.0 \mathrm{ab}$ & $21.0 \mathrm{ab}$ & $14.0 \mathrm{ab}$ \\
\hline TVC & $2.0 \mathrm{c}$ & $4.0 \mathrm{bc}$ & $7.0 \mathrm{bc}$ & $10.0 \mathrm{~b}$ & $11.0 \mathrm{c}$ & $14.0 \mathrm{c}$ & $16.0 \mathrm{~b}$ & $15.0 \mathrm{~b}$ & $10.0 \mathrm{~b}$ \\
\hline GRB & $3.0 \mathrm{ab}$ & $9.0 \mathrm{ab}$ & $11.5 \mathrm{abc}$ & $16.0 \mathrm{a}$ & $21.5 \mathrm{a}$ & $26.5 \mathrm{a}$ & $26.5 \mathrm{a}$ & $27.0 \mathrm{a}$ & $17.0 \mathrm{ab}$ \\
\hline MKG & $2.0 \mathrm{bc}$ & $7.0 \mathrm{abc}$ & $11.0 \mathrm{ab}$ & $14.0 \mathrm{ab}$ & $20.0 \mathrm{ab}$ & $27.0 \mathrm{ab}$ & $28.0 \mathrm{a}$ & $22.0 \mathrm{a}$ & $15.0 \mathrm{ab}$ \\
\hline
\end{tabular}

Non-parametric trend (rate of change in $\Sigma \mathbf{v}$ per year) in DSV accumulation $(\Sigma \mathbf{v})$ during 30-d periods per growing season

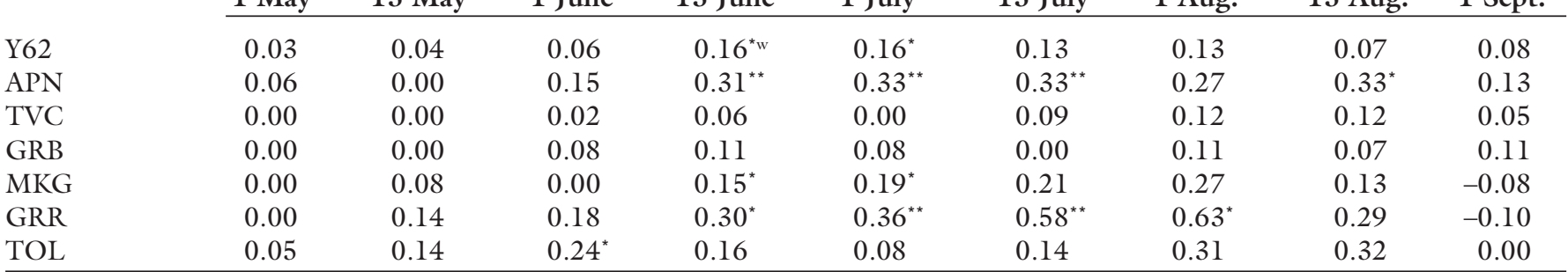

${ }^{2}$ National Weather Service (NWS) station locations: Y62 = Sault Ste Marie, Mich.; APN = Alpena, Mich.; TVC = Traverse City, Mich.; GRB = Green Bay, Wis.; MKG = Muskegon, Mich.; GRR = Grand Rapids, Mich.; TOL = Toledo, Ohio.

y Growing season included 1 May through 30 Sept. (153 d) in all years (1948-99) in analyses.

${ }^{x}$ Within a single column, values followed by the same letter are not significantly different at $\mathrm{P}=0.05$ (Kruskal-Wallis one-way analysis of variance on ranks).

wate of change is significantly greater than zero at $P=0.05\left(^{*}\right)$ or $P=0.01\left(^{* *}\right)$ (Kendall Tau b).

were significant starting 1 June.

Mean 30-d $\Sigma v$ for each location's full growing season are shown in Fig. 3 . $30-\mathrm{d} \Sigma \mathrm{v}$ increased at all locations from May through August, then decreased to the end of the season. The change in environmental conditions conducive to late blight closely mirrored the seasonal pattern of potato canopy leaf area index (LAI), also estimated in Fig. 3. While the exact timing and magnitude of LAI varied with variety, planting date, and growing season, all were observed to have increased from emergence until August, after which the canopy senesced. The mean 30-d $\Sigma v$ values in Fig. 3 which are circled

Fig. 3. Mean 30-d disease severity values (DSV) accumulation with starting dates at 15-d intervals throughout the growing season. Locations are circled where the increase in 30-d DSV accumulation during 1948-99 was significantly greater than zero at the $P$ $=0.05$ level. Associated 30-d accumulation rates of change and significant differences were extracted from Table 6. Estimates of potato canopy leaf area index (LAI) for northern growing regions (e.g., latitude $42 \mathrm{~N}+$ ) are included for each 30-d period (Allen and Scott, 1992). LAI = 3 is considered full canopy.

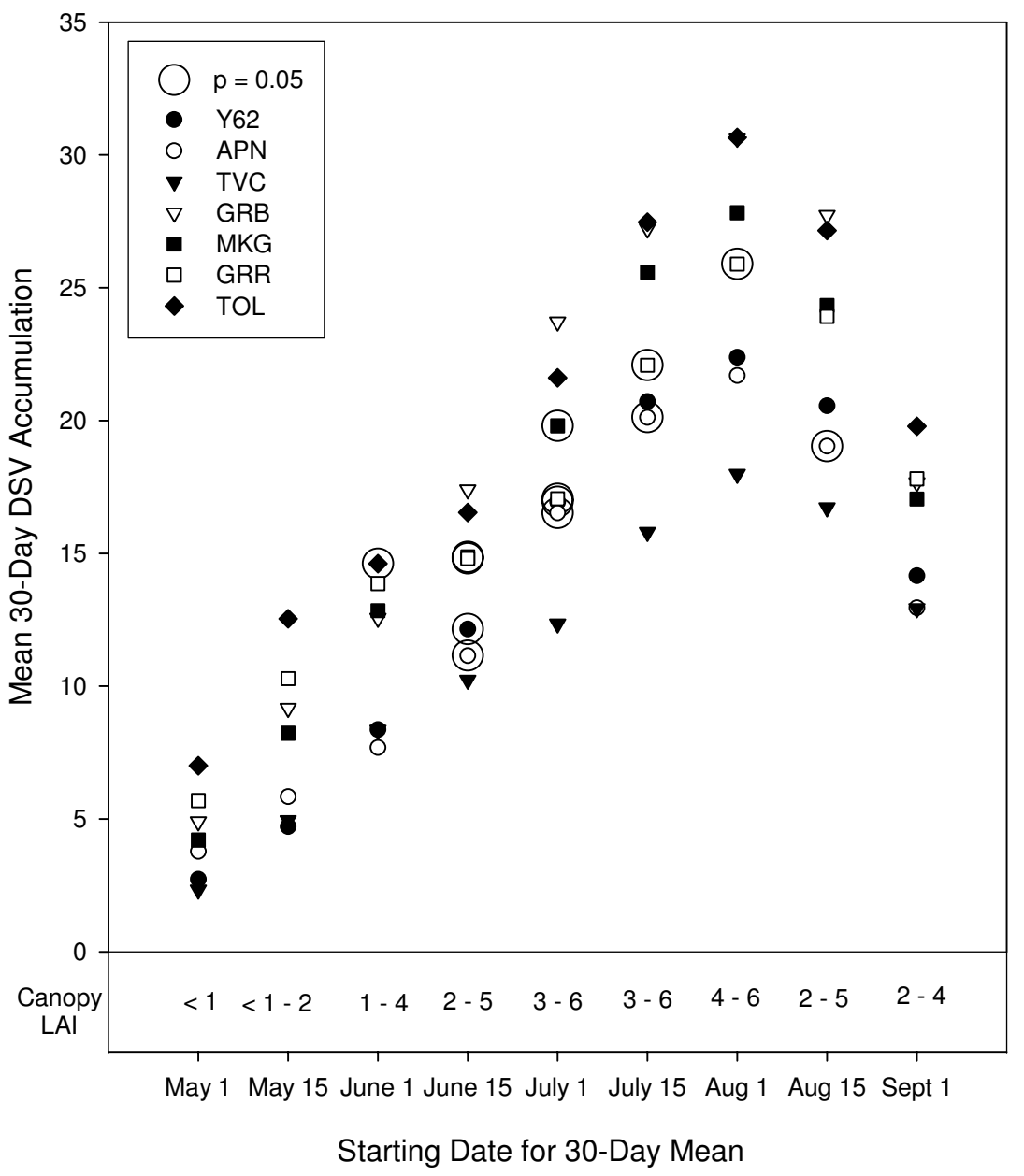


increased significantly in $30-\mathrm{d} \Sigma \mathrm{v}$ from 1948-99 (extracted from Table 6). In most cases, the significant increases occurred during $30-\mathrm{d} \Sigma \mathrm{v}$ periods beginning in June and July, which is earlier in the season than the more typical climatological late blight risk peak in August.

Rate of change statistics for monthly mean dew point and ambient air temperature at the seven locations from 1948-99 are shown in Table 7. For every month, greatest increases in dew point temperatures were found at the Alpena station. The 50-year increase in dew point temperature at Alpena was significantly during the months of July and August, and also for the growing season as a whole. Increases only slightly less than those at Alpena occurred at the two southernmost stations of Grand Rapids and Toledo during June, July, and August, while increases were significantly positive at Grand Rapids in August and at Toledo in July. On a seasonal basis, the total increase in dew point temperature was also significant at Green Bay. While the greatest increases in dew point temperature in terms of magnitude occurred in May at Sault Ste Marie and Alpena, increases at all other locations tended to occur later in the season.

Dry bulb and dew point temperatures were found to increase at most stations throughout the growing season. Dew point temperatures increased particularly during July and August. In contrast to the late season dew point increases, the greatest increases in ambient air temperatures tended to occur in May at most locations. Greatest increases again were observed at Alpena, except in July when the increase was slightly higher at Toledo. The mean air temperature increase was significant at Alpena for the seasonal mean and at Traverse City for July. The only decreases in air temperature occurred at Muskegon from 1948-99 during May, June and September.

\section{Discussion}

Overall, the results suggest that environmental conditions between 1948 and 1999 became more conducive for development of potato late blight throughout Michigan and surrounding areas of the Upper Great Lakes region, within the parameters of what is currently known about the

Table 7. Analysis of rate of change per growing season (1 May through 30 Sept.) at seven locations in the greater Michigan region from 1948-99 for dew point temperature and air temperature.

\begin{tabular}{|c|c|c|c|c|c|c|}
\hline \multirow[b]{2}{*}{ NWS station $^{\mathrm{z}}$} & \multicolumn{6}{|c|}{$\begin{array}{l}\text { Non-parametric trend (rate of change) } \\
\text { in dew point temperature per growing season }\end{array}$} \\
\hline & May & June & July & August & September & Season \\
\hline Y62 & 0.02 & 0.01 & 0.01 & 0.01 & 0.01 & 0.01 \\
\hline $\mathrm{APN}$ & 0.06 & 0.05 & $0.06^{* * x}$ & $0.05^{*}$ & 0.03 & $0.05^{* * *}$ \\
\hline TVC & 0.00 & 0.00 & 0.02 & 0.02 & 0.02 & 0.02 \\
\hline GRB & 0.01 & 0.02 & 0.03 & 0.02 & 0.03 & $0.02^{*}$ \\
\hline MKG & -0.02 & 0.00 & 0.01 & 0.01 & -0.01 & 0.02 \\
\hline GRR & 0.01 & 0.03 & 0.05 & $0.05^{*}$ & -0.01 & 0.03 \\
\hline \multirow[t]{3}{*}{ TOL } & 0.02 & 0.04 & $0.04^{*}$ & 0.02 & 0.00 & 0.02 \\
\hline & \multicolumn{6}{|c|}{$\begin{array}{l}\text { Non-parametric trend (rate of change) } \\
\text { in air temperature per growing season }\end{array}$} \\
\hline & May & June & July & August & September & Season \\
\hline Y62 & 0.03 & 0.02 & 0.01 & 0.01 & 0.01 & 0.01 \\
\hline $\mathrm{APN}$ & 0.05 & 0.03 & 0.02 & 0.02 & 0.03 & $0.02^{*}$ \\
\hline TVC & 0.03 & 0.01 & $0.02^{*}$ & 0.01 & 0.02 & 0.01 \\
\hline GRB & 0.03 & 0.02 & 0.02 & 0.01 & 0.02 & 0.02 \\
\hline MKG & -0.01 & -0.01 & 0.00 & 0.00 & -0.02 & 0.01 \\
\hline GRR & 0.03 & 0.02 & 0.02 & 0.02 & 0.00 & 0.01 \\
\hline TOL & 0.02 & 0.02 & 0.03 & 0.00 & 0.00 & 0.01 \\
\hline
\end{tabular}

${ }^{2}$ National Weather Service (NWS) station locations: Y62 = Sault Ste Marie, Mich.; APN = Alpena, Mich.; TVC = Traverse City, Mich.; GRB = Green Bay, Wis.; MKG = Muskegon, Mich.; GRR = Grand Rapids, Mich.; TOL $=$ Toledo, Ohio

${ }^{y}$ Growing season included 1 May through 30 Sept. (153 d) in all years (1948-99) in analyses.

x Rate of change is significantly greater than zero at $P=0.05\left({ }^{*}\right), P=0.01\left({ }^{* *}\right)$, or $P=0.001\left(^{* * *}\right)$ (Kendall Tau b).

influence of temperature and relative humidity on late blight development. Risk of infection has also been increasing with the advent of metalaxyl-insensitive strains of $P$. infestans and tightening fungicide regulations. Host resistance does not seem to be a viable solution to late blight risk in the immediate future. Considered collectively, these trends suggest that disease management for potato production has become relatively more difficult through time in the Upper Great Lakes region.

The increase in late blight risk, as measured by at least one of the risk indicators derived from DSV estimates, was statistically significant at every location.

Conditions at Alpena and Grand Rapids became significantly more conducive for the development of late blight over the period from 1948 to 1999 in the greatest number of tested indicators used to estimate risk. Risk indicators such as $\Sigma \mathrm{v}, \Sigma \mathrm{x}_{\mathrm{v}}$, and 30 -d $\Sigma \mathrm{v}$ in June and July also increased significantly at Sault Ste Marie and Muskegon. The lowest rate of change in disease risk of any location was found at Traverse City, where the only significant positive change in risk-re- lated indicator was the number of 5-d intervals with an accumulation of at least 10 disease severity values.

$\Sigma \mathrm{v}$ per growing season, used in this study as an indicator of overall growing season late blight risk, increased at all stations from 1948-99, and at all locations there was a decrease in the number of days with little or no late blight risk $\left(\Sigma \mathrm{x}_{0}\right)$. In addition, the number of days of each day type indicated that late blight risk from minimal $\left(\Sigma \mathrm{x}_{1}\right)$ through severe $\left(\Sigma \mathrm{x}_{4}\right)$ levels increased or at least remained constant at each location.

Fungicide applications are often initiated or increased following accumulation of specific DSV-related thresholds. The results of this study illustrate that the time that these thresholds were reached closely corresponded with the time of "full" potato canopy $(\mathrm{LAI}=3)$. Although Wallin-based DSV systems have been used extensively to monitor late blight risk, knowledge of the canopy environment may be the most important for growers in terms of making fungicide recommendations. This result questions the usefulness of DSV type systems.

A DSV-type system may be most useful with respect to identifying ex- 
tremely conducive periods in the growing season (e.g., 5-d periods with at least 10 DSVs). However, it is difficult for growers to respond to these periods as heavy precipitation totals that favor late blight development also make field operations (such as spraying) difficult. The high precipitation and humidity typical during high-risk periods, are also easily identifiable without a DSV system. Future research should focus on the usefulness of DSV-type late blight risk systems.

As shown in Fig. 3, ambient environmental conditions most favorable for late blight occurred during August coincident with peak leaf area index (LAI) in the potato canopy. This period is crucial because when $\mathrm{LAI} \geq 3$, canopy conditions have become relatively more conducive to late blight than ambient conditions might suggest. Both air flow and light penetration decrease as LAI increases, resulting in a greater likelihood of late blight development because of higher leaf wetness duration in the canopy. Significant increases in conducive conditions as measured by $30-\mathrm{d} \Sigma \mathrm{v}$ occurred during June and July, prior to the August peak in late blight risk. This result is important in terms of foliar fungicide spray timing early in the season (e.g., shortly after emergence, especially in June). The period of increasing risk spans the period of canopy development, from just after emergence in June to the August peak in measured late blight risk indicators, indicating that from 1948 to 1999 higher late blight risk occurred more quickly after emergence and remained higher for longer periods of time (e.g., during times of full canopy development).

When 30-d trends in the environmental variables of dew point and ambient air temperature were analyzed, ambient air temperature increased most frequently in May. This result suggests an earlier spring warm up and a possible lengthening of the growing season, which agrees with the findings of previous research in the region (e.g., Andresen and Harman, 1994). Growth of the potato canopy occurs with development and expansion of individual leaves and the rate of development and expansion increases with increasing temperatures. Warmer temperatures in May lead to greater LAI earlier in the season, creating a canopy microclimate more conducive to late blight development at the same time as larger scale weather patterns are also increasing late blight risk.

Increases in dew point temperatures, by contrast, were found to have been less frequent in May than during the rest of the growing season. This result would suggest an increase in growing season moisture throughout the Upper Great Lake region in June, July, August, and September. Because the rate of change in late blight risk was greatest in June and July, when dew point temperatures are increasing as opposed to ambient air temperatures, increasing moisture is most likely impacting the accumulation of DSV more than the change in temperature. The accumulation of fungicide spray threshold values earlier in the season, is likely also being impacted more by the increase in dew point temperatures in June and July than the earlier spring warm up. Median time to threshold values across locations corresponded to estimates of full canopy conditions.

Increases in dew point and air temperature are supported by the research of Karl and Knight (1998) on trends in precipitation in the U.S., which estimated a $10 \%$ increase in the annual precipitation as a national average in the last 80 years (1998). During this time, heavy and extreme precipitation events began to contribute a greater portion of the total precipitation in both single and multiple day precipitation events. The increasing frequency of these events may be one of the factors influencing the increase of highly conducive 5 -d intervals. The annual number of days with precipitation also increased in the contiguous U.S. (Karl and Knight, 1998).

In the Great Lakes region, precipitation amounts have risen approximately $0.4 \mathrm{~mm}$ (0.016 inch) per year since 1895 , with a significantly greater number of wet days following wet days (Andresen et al., 2001). These increases in annual precipitation, number of days with precipitation, and the number of wet days following wet days are each expected to have increased risk of potato late blight infection and subsequent yield and economic losses.

\section{Conclusion}

Across portions of the Upper Great Lakes region, increasingly favorable environmental conditions have likely led to relatively greater risks of potato late blight. The most consistent indicators of environmental change across Michigan were: 1) increases in total DSV $(\Sigma \mathrm{v})$ per growing season, 2$)$ the decrease in number of days with 0 DSVs (conditions not conducive to late blight development), and 3) the increase in the number of days per season with 2 DSVs (conditions moderately conducive to late blight development). These results suggest that in this region the resurgence of potato late blight reported in Fry and Goodwin (1997) may be due not only to metalaxyl-insensitive genotypes, but also to an increase in the frequency and duration of environmental conditions conducive to late blight as well as earlier canopy development brought about by warmer early season temperatures.

Future research should also explore long-term trends of other weather-based plant pathogen and host systems. Results from this and similar trend analyses could then be used as a baseline to compare the effects of various climate change scenarios on pathogen systems. New data sources, such as NEXRAD precipitation data, might also provide new research opportunities for estimating potato late blight risk on finer spatial scales. With respect to $P$. infestans, the usefulness of DSV-type late blight risk systems should be analyzed and the threshold values for both relative humidity and temperature should be reevaluated.

\section{Literature cited}

Allen, E. and R. Scott. 1992. Principles of agronomy and their application in the potato industry, p. 816-881. In: P. Harris (ed.). The potato crop. Chapman and Hall, London.

Andresen, J., G. Alagarswamy, C. Rotz, J. Ritchie, and A. LeBaron. 2001. Weather impacts on maize, soybean, and alfalfa production in the Great Lakes region, 1895-1996. Agron. J. 93:1059-70.

Andresen, J.A. and J.R. Harman. 1994. Springtime freezes in western lower Michigan: Climatology and trends. Michigan State Univ. Agr. Expt. Sta. Res. Rpt. 536, East Lansing.

Baker, K.M., J.A. Andresen, W.W. Kirk, and J.M. Stein. 2000. Crop disease mitigation: Daily risk modeling for Michigan potato growers. 4th Intl. Conf. on Integrating GIS and Environ. Modeling (GIS/EM4): Problems, Prospect and Res. Needs, Banff, Alberta, Canada. 


\section{WORKSHOP}

Fry, W.E. and S.B.Goodwin. 1997. Resurgence of the Irish potato famine fungus. BioScience 47:363-371

Karl, T. and R. Knight. 1998. Secular trends of precipitation amount, frequency, and intensity in the United States. Bul. Amer. Meteorol. Soc. 79:231-241.

Lacy, M.L. and R. Hammerschmidt. 1995. Diseases of potato: Late blight. E1802, Ext. Bul. Mich. State Univ., East Lansing.

MacKenzie, D.R. 1981. Scheduling fungicide applications for potato late blight with BLIGHTCAST. Plant Dis. 65:394-399.

National Climatic Data Center. 2004. World's largest archive of climate data. 2 Mar. 2004. <http://cdo.ncdc.noaa. gov/cdo/info.html $>$.

Robinson, P. 2000. Temporal trends in United States dew point temperatures. Intl. J. Climatol. 20:985-1002.

Sen, P. 1968. Estimates of the regression coefficient based on Kendall's tau. J. Amer. Stat. Assn. 63:1379-1389.

Wallin, J.R. 1962. Summary of recent progress in predicting late blight epidemics in United States and Canada. Amer. Potato J. 39:306-312.

Wallin, J.R. and M.L. Schuster. 1960. Forecasting potato late blight in western $\mathrm{Ne}$ braska. Plant Dis. Rptr. 44(12):896-900. 